\title{
Impact of spatio-temporal shade dynamics on wheat growth and yield, perspectives for temperate agroforestry
}

\author{
Sidonie Artru ${ }^{\mathrm{a}, *}$, Sarah Garréb ${ }^{\mathrm{b}}$, Christian Dupraz ${ }^{\mathrm{c}}$, Marie-Pierre Hiel ${ }^{\mathrm{a}}$, \\ Céline Blitz-Frayret ${ }^{\mathrm{c}}$, Ludivine Lassois ${ }^{\mathrm{b}}$ \\ a TERRA research center - AgricultureIsLife, University of Liège, Gembloux Agro-Bio Tech, Passage des Déportés 2, B-5030 Gembloux, Belgium \\ b TERRA research center, University of Liège, Gembloux Agro-Bio Tech, Passage des Déportés 2, B-5030 Gembloux, Belgium \\ ${ }^{\mathrm{c}}$ INRA, UMR SYSTEM, Equipe Amplus, Bâtiment 27, 2, Place Viala, 34060 Montpellier Cedex 1, France
}

\section{A R T I C L E I N F O}

\section{Article history:}

Received 10 March 2016

Received in revised form

30 September 2016

Accepted 9 October 2016

Available online 8 November 2016

\section{Keywords:}

Winter wheat

Spatio-temporal shade

Grain yield

Modeling

Agroforestry system

\begin{abstract}
A B S T R A C T
A stumbling block to the adoption of silvoarable agroforestry systems is the lack of quantitative knowledge on the performance of different crops when competing for resources with trees. In North-Western Europe, light is likely to be the principal limiting resource for understorey crops, and most agronomic studies show a systematic reduction of final yield as shade increases. However the intensity of the crop response depends on both the environmental conditions and the shade characteristics. This study addressed the issue by monitoring winter wheat (Triticum aestivum L.) growth, productivity and quality under artificial shade provided by military camouflage shade-netting, and using the Hi-sAFe model to relate the artificial shade conditions to those applying in agroforestry systems.

The field experiment was carried out over two consecutive years (2013-14 and 2014-15) on the experimental farm of Gembloux Agro-Bio Tech, Belgium. The shade structures recreated two shade conditions: periodic shade (PS) and continuous shade (CS), with the former using overlapping military camouflage netting to provide discontinuous light through the day, and the latter using conventional shade cloth. The experiment simulated shading from a canopy of late-flushing hybrid walnut leaves above winter wheat. Shading was imposed 16 (2013-14) and 10 (2014-15) days before flowering and retained until harvest. The crop experienced full light conditions until the maximum leaf area index stage $\left(\mathrm{LAI}_{\max }\right)$ had been reached. In both years, LAI followed the same dynamics between the different treatments, but in 2013-2014 an attack of the take-all disease (Gaeumannomyces graminis var. tritici) reduced yields overall and prevented significant treatment effects. In season 2014-15 the decrease in global radiation reaching the crop during a period of 66 days (CS: $-61 \%$ and PS: $-43 \%$ ) significantly affected final yield (CS: - 45\% and PS: - 25\%), mainly through a reduction of the average grain weight and the number of grain per $\mathrm{m}^{2}$. Grain protein content increased by up to $45 \%$ under the CS treatment in 2015 . Nevertheless, at the plot scale, protein yield ( $\mathrm{t} / \mathrm{ha}$ ) did not compensate for the final grain yield decrease.

The Hi-sAFe model was used to simulate an agroforestry plot with two lines of walnut trees running either north-south or east-west. The levels of artificial shade levels applied in this experiment were compared to those predicted beneath trees growing with similar climatic conditions in Belgium. The levels used in the CS treatment are only likely to occur real agroforestry conditions on 10\% of the cropped area until the trees are 30 years old and only with east-west tree row orientation.
\end{abstract}

(c) 2016 Elsevier B.V. All rights reserved.

\section{Introduction}

In 2014, winter-wheat (Triticum aestivum $\mathrm{L}$.) represented around $14 \%$ of the cultivated area in Belgium with a mean yield of 9.9 tha $^{-1}$ (Waeyaert, 2014). Winter-wheat represents $29 \%$ of the cereal production on the world market (FAO, 2014), but at the same time,

\footnotetext{
* Corresponding author.

E-mail address: sidonie.artru@ulg.ac.be (S. Artru).
}

the intensive agricultural practices used to produce the crop lead to environmental problems like soil erosion, water pollution and loss of biodiversity. These facts challenge us to come up with alternative farming systems, such as mixed cropping (Malézieux et al., 2009). The combination of crops and woody components in a same field is called agroforestry and it can combine good productivity with sustainable land use (Dupraz, 2002). However, the success of such systems depends on the reinforcement of ecological processes such as facilitation and complementarity for resource capture between species (Cannell et al., 1996; Malézieux et al., 
2009). Complementarity is constrained if all plants use the same resources and the consequences can be severe in an environment where one resource is limiting (Ong and Huxley, 1996). In a successful agroforestry system, complementarity results from niche differentiation, either in space (e.g. different root depth) or in time (e.g. different phenology) (Tilman and Snell-Rood, 2014). In this context, research on agroforestry systems aims at quantifying and analyzing the spatiotemporal patterns of resource capture between species. However, papers covering temperate agroforestry systems reveal contrasting results (Luedeling et al., 2016; Smith et al., 2013; Tsonkova et al., 2012). This is probably due to the fact that the interactions between two different species may depend on multiple factors such as the design of the mixture (e.g. species choice, stand design ...), the management choices (e.g. tree pruning height, tillage depth ...) and soil and climate conditions. This makes a clear overview difficult (Batish, 2008; Jose and Gordon, 2008; Zhu et al., 1991). Nevertheless, with regard to factors hampering the performance of silvoarable agroforestry systems, light might be the principal limiting resource for the crop growing under trees subjected to Belgian soil and climate conditions (Eichhorn et al., 2006). The tree induces a heterogeneous light environment for the crop species below. A tree canopy leads to a typical sunfleck regime, varying, on one hand, within a time frame of seconds to minutes due to penetration of the sun through the canopy and wind induced movements, and on the other hand over days, months and years depending on the path of the sun, tree planting density, silvicultural practices and tree phenological stage (Leroy et al., 2009; Liu, 1991; Talbot and Dupraz, 2012). Alterations of light quantity and quality during the cropping season will induce physiological and morphological changes for the crop.

Previous studies tested the effect of shade on crop growth and yield by applying shade at a specific moment in the development cycle and during the whole day rather than at a specific time during the day, as is observed under trees (Demotes-Mainard and Jeuffroy, 2004; Fischer and Stockman, 1980). Only a few research projects have looked at the agronomical impact of the light regime experienced by crop species under temperate agroforestry systems (Chirko et al., 1996; Dufour et al., 2013; Friday and Fownes, 2002; Gillespie et al., 2000; Liu, 1991; Mu et al., 2010; Zhang et al., 2008). These studies show a systematic reduction of final crop yield but the intensity of this decrease varies between species, as does the shade level and possible below-ground interactions. In order to differentiate the effect of light from the other possible abiotic and biotic interactions occurring between trees and crops in agroforestry system, several authors designed and used an artificial shade system (Dufour et al., 2013; Peri et al., 2002; Varella et al., 2010). Earlier articles evaluated the ability of artificial shade materials to mimic the fluctuating agroforestry light environment over the day or through the cropping season. Varella et al. (2010) demonstrated that wooden slatted structures reproduced well the daily periodic light fluctuation and the spectral composition observed under trees. In comparison, conventional plastic shade-cloth only produced a predetermined level of light reduction. Dufour et al. (2013) presented the potential of adding overlapping shade cloths during the cropping season in order to mimic the increasing leaf area of trees. These artificial structures were used to analyze crop and forage development, yield and physiological responses to shade (Dufour et al., 2013; Peri et al., 2002; Varella et al., 2010).

The general aim of the current study is to quantify the efficiency of winter wheat growth, productivity and quality in temperate conditions, under the shade of late-budding trees, replicated by an artificial shade system. In order to take into account the diversity of possible shade environment observed under agroforestry, crops have been subjected to two distinct shade conditions thus addressing two objectives. The first is a worst-case scenario of crop response to an extreme condition of continuous shade under the temperate climate conditions. The second is to monitor the response of crops to variable shade by changing the shade hourly. Finally, we aimed to compare the artificial shade conditions with real agroforestry systems through a modelling approach.

\section{Materials and methods}

\subsection{Field experiment}

The experiment was conducted during two growing seasons, 2013-14 and 2014-15, at the experimental farm of Gembloux AgroBio Tech $\left(50^{\circ} 33^{\prime} \mathrm{N}, 4^{\circ} 42^{\prime} \mathrm{E}\right)$, in the Hesbaye region, Belgium. The climate is temperate maritime, with an average annual temperature of $10.1^{\circ} \mathrm{C}$ and mean annual rainfall of $799 \mathrm{~mm}$ over a 20 year period (1994-2014). The soil is classified as Luvisol (FAO, 2014). The plots were both part of the experimental farm in both years, but they were not exactly at the same spot in the field. Soil physicochemical homogeneity within and between both experimental plots was previously verified using the digital soil map of Wallonia and a measurement of soil electrical conductivity (EC) realized using the electromagnetic induction method (EMI) (Bah et al., 2005; Grisso et al., 2005) conducted prior to the installation of the artificial shade structures.

Winter wheat (T. aestivum L., cultivar Edgard) was planted on October 24th, 2013 (300 grains $\mathrm{m}^{-2}$ ) and October 21th, 2014 (250 grains $\mathrm{m}^{-2}$ ), the drill lines following an East-West orientation in both cases. The preceding crops were winter wheat in 2013-2014 and rapeseed in 2014-2015. Fertilization followed the conventional practice applied in Belgium, which means that three doses of nitrogen fertilizers were applied throughout the growing season. A total amount of $225(75,75,75)$ and 175 (50, 50, 75 ) units of nitrogen per hectare and per year were applied, respectively for the season 2013-2014 and 2014-2015. For both cropping seasons, one herbicide (pyroxulamn (7.1\%), florasulam (1.5\%), cloquintocet-mextyl (7.1\%) and colza oil), one plant growth regulator (chlormequat chloride (59.7\%) and cholin chloride (3.2\%)) and two fungicides (one composed of epoxiconazool $(37.5 \mathrm{~g} / \mathrm{l})$ and metconazool (27.5 g/l); the other composed of bixafen $(75 \mathrm{~g} / \mathrm{l})$ and prothioconazole $(150 \mathrm{~g} / \mathrm{l})$ ) were applied in spring. Winter wheat was harvested on August 5th, 2014 and August 10th, 2015 with a combine harvester.

\subsection{Experimental design}

The experiment included three shade levels, corresponding to three modes of daily shade dynamics. The continuous shade (CS) treatment underwent shade throughout the entire day; the periodic shade treatment (PS) corresponded to an intermittent shade on the plot varying during the day; while the crop in the no shade treatment (NS) received $100 \%$ of the available light. Within the PS plot, the variability of shade dynamics was assessed by measuring the light availability for the winter wheat at three locations along the north-south transect, defined as PS1, PS2, PS3. The shade levels were obtained by adjusting shade layers on the south face of a greenhouse tunnel structure ( $5 \mathrm{~m}$ wide, $68 \mathrm{~m}$ long and $2.50 \mathrm{~m}$ in height) set up in East-West orientation (Fig. 1). We used camouflage nets as shade material to reproduce a rapidly fluctuating sun/shade pattern. The proportion of holes to cloth in the mesh of the camouflage nets produces a combination of direct and diffuse light patches. The artificial shade was designed to mimic the shade dynamics of a hybrid walnut and was adapted to follow the development of tree-foliage in a monitoring plot in Belgium. In 2014-15, the camouflage net covered $40 \mathrm{~cm}$ more of the tunnel curvature than in 2014-15, in order to induce a higher overall shade level in the PS treatment. The surface of cloth was extended by around $9 \%$ 


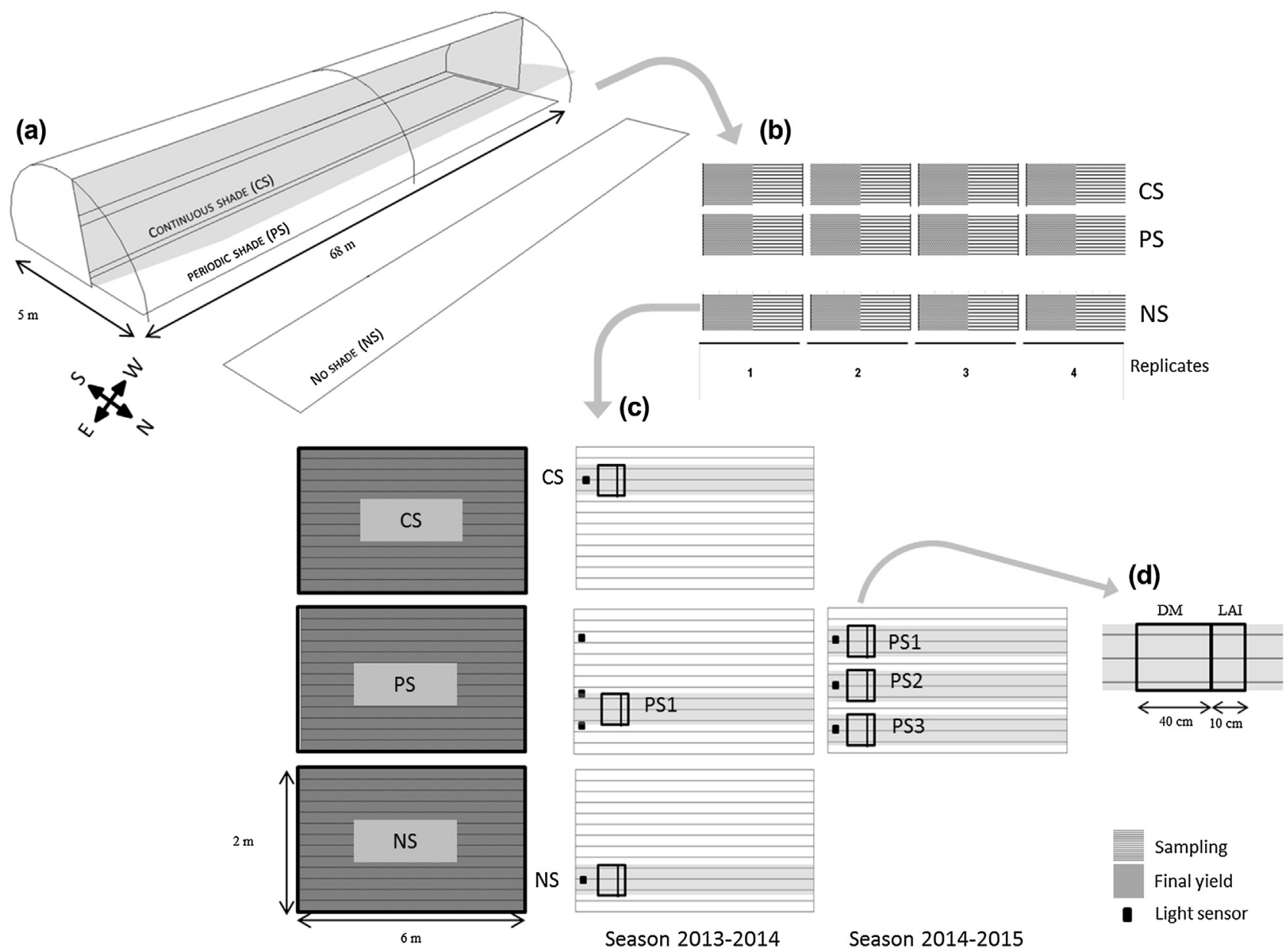

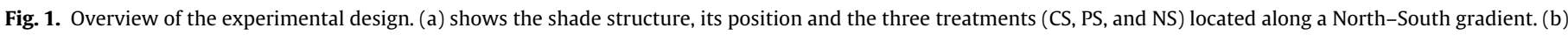

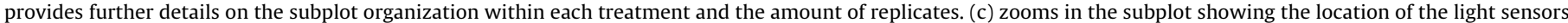
and (d) an example of a typical sampling in the PS plot (DM = dry matter, LAI = Leaf area index).

as compared to the initial surface. Under the tunnel structure, the layout included four replicate blocks, each made up of two subplots $(6 \mathrm{~m} \times 2 \mathrm{~m})$. One of the sub-plots was used for periodic destructive sampling of wheat plants during the growing season, and the other was maintained undisturbed for final yield quantification at harvest (Fig. 1).

\subsection{Data collection}

\subsubsection{Tree phenology monitoring and reproduction of shade dynamics}

We monitored the phenological development of trees in a hybrid-walnut plantation in Jenneret, Condroz region, Belgium $\left(50^{\circ} 24^{\prime} \mathrm{N}, 5^{\circ} 27^{\prime} \mathrm{E}\right)$. The 60 walnut trees were planted in 1991 with an average distance between trees of $8 \mathrm{~m}$. Three phenological stages were documented during the growing season (May-November): budburst, end of leaf expansion and leaf fall. The date at which a phenological stage is achieved was defined as the date when $50 \%$ of the trees of the plantation reached the stage.

In the artificial shade experiment, the first layer of camouflage net was installed over the crop after budburst when all buds had a first leaf expanded and induced a significant shade (qualitative visual observation). Subsequently, tree foliage expansion was imitated by superimposing a second layer of camouflage net. At wheat maturity, the shade layers and greenhouse structure were removed for harvesting. For the season 2013-14, the first layer of camouflage net was applied 213 days after wheat sowing (DAS) (May 24th) and the second from 238 DAS (June 18th) until 274 DAS (July 25th), after which the shade was removed. The wheat was harvested only 11 days later due to rainy conditions (285 DAS, August 5th). A total of 61 days of shade was applied during the growing season 2013-14. In 2014-15, the first layer was applied 226 DAS (June 4th) and the second from 245 DAS (June 23rd) until harvest 292 DAS (August 10th). A total of 66 days of shade was applied during the growing season 2014-15 (Fig. 2).

\subsubsection{Agronomic measurements}

We sampled winter wheat to assess aboveground biomass dry matter (DM) and leaf area index (LAI). Samples were taken from three adjacent sowing lines of $40 \mathrm{~cm}$ width for DM and three adjacent $10 \mathrm{~cm}$ bands for LAI. For the PS plots, the same three bands were used throughout the four replicates to ensure the same light conditions (PS1, PS2, and PS3) (Fig. 1). The final grain yield (t/ha) was obtained by harvesting the entire undisturbed plot $\left(12 \mathrm{~m}^{2}\right.$ per replicate), resulting in one single yield value for the entire PS plot (Fig. 1). Dry matter was assessed at four dates in 2014 (158, 178, 199, 220 DAS) and six dates in 2015 (197, 225, 240, 253, 268, 274, 290 DAS). LAI was measured at three dates in 2014 (158, 178, 199 DAS) and four dates in 2015 (197, 225, 240, 253 DAS).

To assess dry matter distribution, wheat plants were subdivided in spikes and straw, dried $\left(60^{\circ} \mathrm{C}\right.$ for 10 days) and weighed. LAI was determined by scanning the surface of the plant leaves. Then LAI was defined as the total green leaf area per unit ground surface area. The final yield is expressed in $\mathrm{t} /$ ha at $15 \%$ humidity. We 


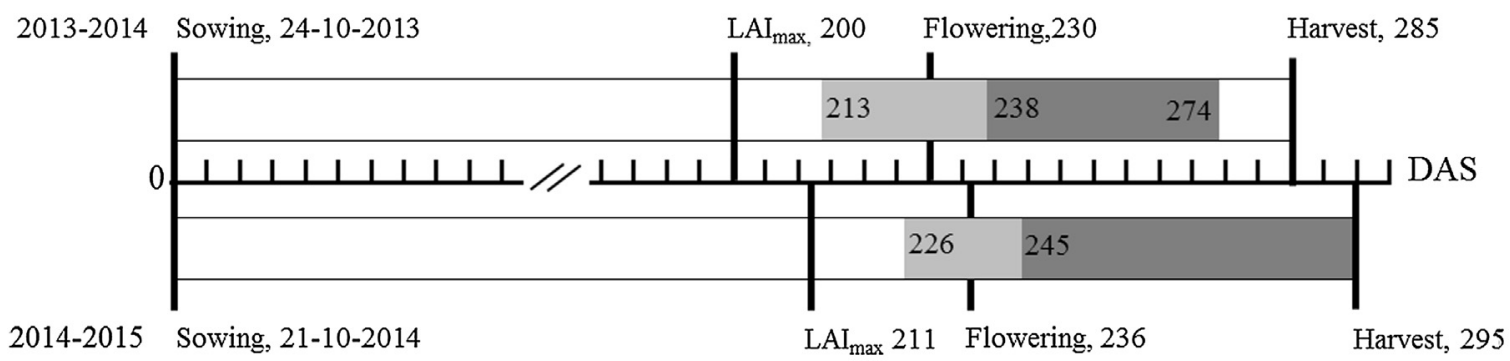

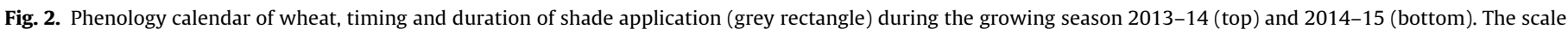

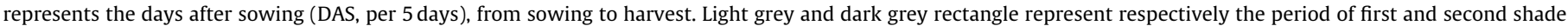
layer installation.

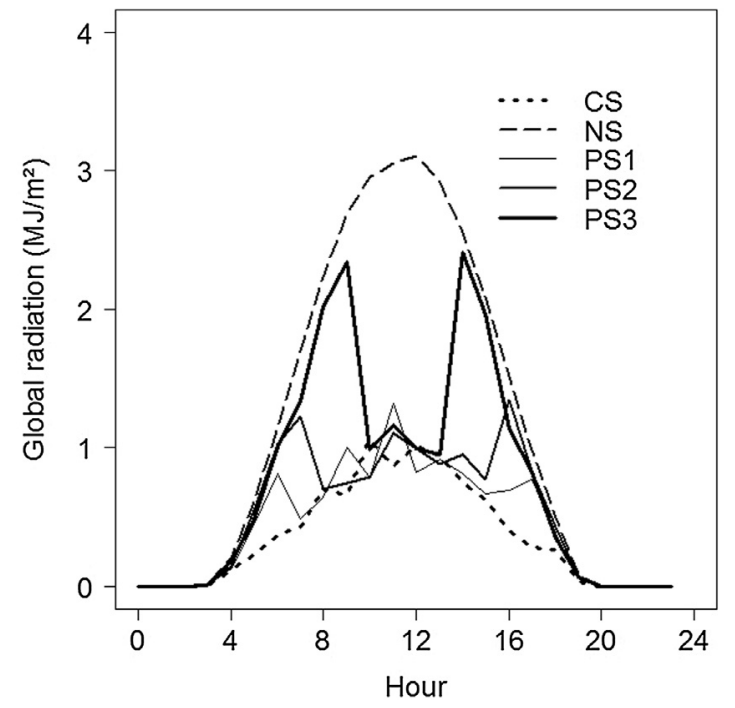

Fig. 3. Example of daily dynamic of global radiation $\left(\mathrm{MJ} / \mathrm{m}^{2}\right)$. The global radiation was measured on July 3rd 2015 under the no shade (NS), continuous shade (CS) and periodic shade (PS1, PS2, PS3) treatments.

assessed grain weight, grain size (using 3 sieves: $2.8,2.5,2.2 \mathrm{~mm}$ ) and grain protein content on subsamples from the harvested plots. Protein content (\%) analyses were performed with the near-infrared reflectance spectroscopy technique (Rapid Content Analyzer, XM1100 Series). We calculated the number of grains per $\mathrm{m} 2$ from thousand kernel weight (g/1000 grains) and yield (t/ha). Harvest index (HI) is defined as the ratio of the grain weight to the total plant aboveground biomass. It should be mentioned that in 2014, the winter wheat was attacked by the take-all fungus (Gaeumannomyces graminis var. tritici).

\subsubsection{Global radiation measurements}

Daily global radiation was recorded from October to April 2014, by a weather station from the Royal Meteorological institute, located $3 \mathrm{~km}$ from the experimental site (Ernage, Gembloux, $50^{\circ} 59^{\prime} \mathrm{N}, 1724^{\circ} 67^{\prime} \mathrm{E}$ ) and from May 2014 to August 2015 by a local weather station (CR800-Campbell Scientific Inc., USA) installed near the experimental plots (Bordia, Gembloux, $50^{\circ} 56^{\prime} \mathrm{N}, 4^{\circ} 71^{\prime} \mathrm{E}$ ) (Fig. 3). As soon as the shade structure was set up, global radiation at crop canopy level was measured with quantum sensors (CS300 - Campbell Scientific Inc., USA - accuracy $\pm 5 \%$ for the daily global radiation) and recorded every minute by data loggers (CR1000-Campbell Scientific Inc., USA). In 2013-14, two sets of five sensors were installed in parallel along the three shade treatments. For the final analysis, an average value of each sensor pair along the shade gradient was used. For the season 2014-15 only one set of five sensors was used: one was installed under the CS plot, another in the NS plot and three under the PS plot (Fig. 1). During the season 2013-14, two of these sensors (PS2 and PS3) were located close to the three wheat drill rows monitored during the growing season, the third (PS1) was at the extremity of the plot. Thus, we used the PS2 and PS3 mean global radiation value to analyze wheat growth development (PS). For the season 2014-15, each of the three sensors was located in sampling area (PS1, PS2, and PS3). Under the PS treatment, the hourly pattern of global radiation varied from one row to another. We therefore characterized the global radiation intercepted by the whole PS plot using a spatial average of the global radiation. Thus PS was calculated as a weighted average in which global radiation intercepted by the PS1, PS2, and PS3 sensors was weighted corresponding to the proportion of the PS plot area.

\subsection{Modelling approach}

In order to interpret our results in terms of real agroforestry systems, we used the Hi-sAFe model (Dupraz et al., 2005) to predict the long-term global radiation availability for crops growing under hybrid walnut in the Belgian climate. This process-based model includes the 3-D light competition module sAFe-Light, previously validated by field measurements (Talbot and Dupraz, 2012). The virtual agroforestry plots are defined as rectangles divided in square cells of $1 \mathrm{~m}^{2}$, which can either host crops, trees, or both. Trees are represented by an ellipsoid crown, linked to the diameter at breast height and to the trunk height by allometric relationships. Within this configuration, daily incident global radiation at plot scale can be assessed from a spatial average of incident global radiation on each of the crop cells.

In this study, simulations were conducted on plot where the tree lines are spaced at $35 \mathrm{~m}$ and the trees in the line are $7 \mathrm{~m}$ apart, with a $1 \mathrm{~m}$ uncropped strip along the tree row. For the tree rows orientation, a north-south and an east-west scenario have been followed. The simulations were carried out with weather data recorded from 1980 to 2013 by the Royal Meteorological institute. Nevertheless, in order to perform simulations over a period of 50 years, a 17year climatic series was generated through a random selection of the observed data. At the end of the simulation, radiation availability for the crop throughout the evolution of the agroforestry system was assessed at the level of the square cells in order to have a detailed map of the light repartition within the plots. The radiation proportion was expressed as the ratio between the incident radiation available under the trees to that above the trees.

\subsection{Statistical analyses}

All statistical analyses were performed with the $\mathrm{R}$ software. Analyses of variance (ANOVA) and Tukey range tests were used to assess the effect of the shade treatments on crop growth (DM, 

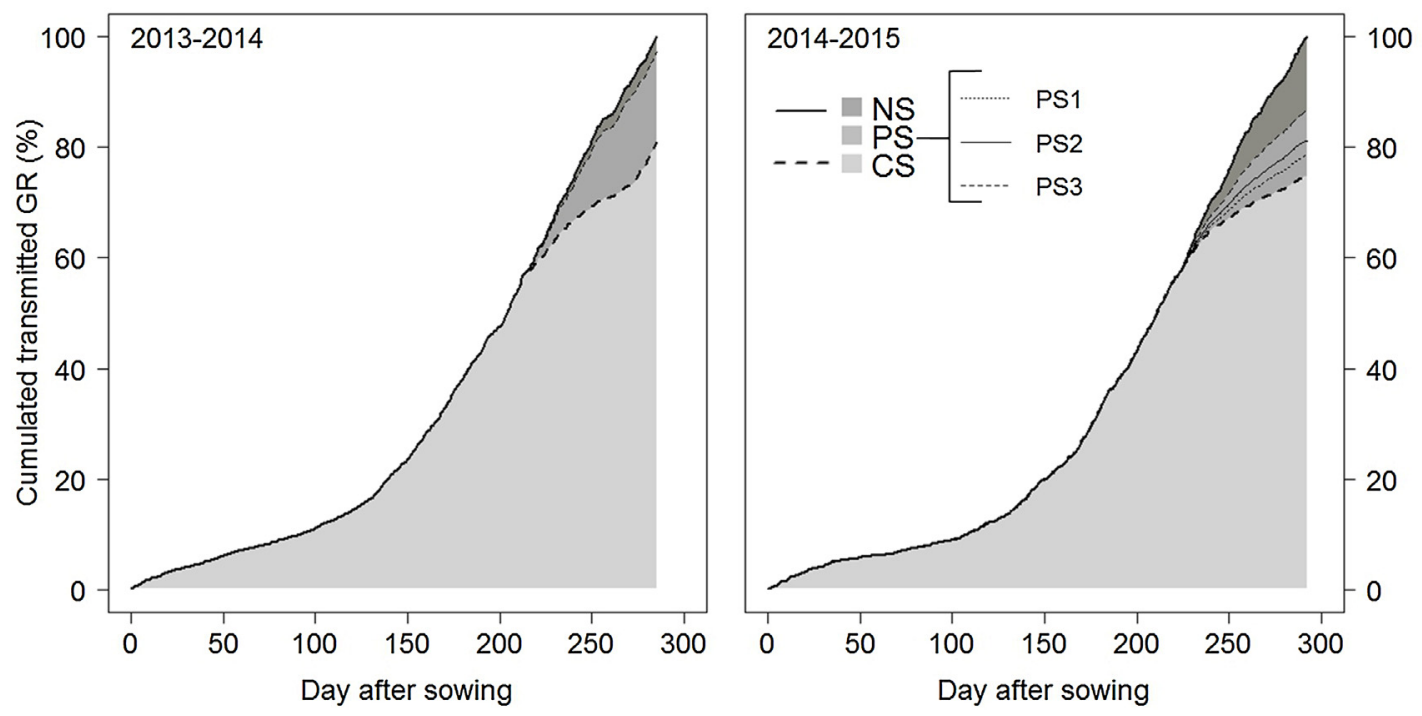

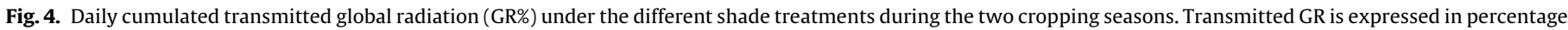
of the GR cumulated in full sun (NS) at the end of the cropping seasons. Vertical bars indicated the date of shade layers applications during the cropping seasons.

LAI), final yield, yield components (thousand grain weight, grains size proportion and harvest index) and protein rate.

\section{Results}

\subsection{Global radiation transmitted below the artificial shade treatment}

The analysis of the global radiation dynamics was assessed both diurnally and seasonally. At the diurnal time scale, the wheat experienced a continuous shade regime over the day in the CS treatment, while the global radiation varied depending on the distance to the shade structure under the PS treatment. Fig. 3 shows an example of the diurnal variation of the global radiation for a transect from NS over PS (PS1, PS2, PS3) to CS on July 3rd, 2015. It illustrates the spatial gradient and the temporal dynamics of the light penetrating the artificial shade structure. Summarizing these diurnal variations for each treatment over the entire growing season, we observe the following average behavior and extremes. During the season 2013-14, a maximum of 283 min of shade was measured per day by the PS1 sensor and around $35 \mathrm{~min}$ by the sensor PS2-3. On average, these sensors measured 86 and $11 \mathrm{~min}$ of shade respectively. Due to the slightly larger surface of the camouflage net in 2014-15, the PS plot experienced a longer period of shade on average than in 2013-14. The PS1, PS2 and PS3 sensors registered a maximum period of dense shade (as observed under the CS treatment) of 369, 335 and 229 min respectively. Fig. 4 shows the cumulative transmitted global radiation from sowing until harvest for both seasons. At the scale of the growing season, we applied shade 72 (2014) and 66 (2015) days before harvest on a total growing period of 285 and 292 days, respectively. The result is a minor reduction of cumulated transmitted global radiation over the whole growing season, ranging from 19 to $3 \%$ compared to the cumulative radiation without shade in 2014 and from 25 to $14 \%$ in 2015 depending on the distance to the shade structure.

With respect to the phenological development of the crop, we observed different cumulative radiation for the three main periods in the growing cycle with distinct shade patterns: sowing$\mathrm{LAI}_{\max }, \mathrm{LAI}_{\max }$-flowering and flowering-harvest. The LAI $\mathrm{I}_{\max }$ stage is reached when all leaves are fully expanded (Table 1 ). Thus, winter wheat experienced similar light conditions before its LAI max stage in both years. Then, from flowering to harvest, the global radiation received by the crop in the CS treatment was reduced by $45 \%$ in 2014 and $65 \%$ in 2015 . For the PS treatment, it varied from $6 \%$ to $14 \%$ in 2014 and from $35 \%$ to $55 \%$ in 2015 (Table 1).

\subsection{Wheat biomass and LAI responses under shade}

Due to the lag in phenological development of hybrid walnut as compared to winter wheat, for both experimental years, the shading treatment did not affect $\mathrm{LAI}_{\max }$ and no significant difference emerged when quantifying LAI dynamics of the different treatments.

Looking at the aboveground biomass dynamics, the straw and spike dry matter followed a similar trend over the growing season under the different global radiation conditions for both experimental years. Straw biomass increased until mid-June and then decreased upon leaf senescence, while spike biomass increased gradually from mid-June until grain maturity. During the first year (2013-14), straw and spike biomass were not significantly affected by the shading treatments at flowering (Fig. 51-2). In the same season, straw biomass measured 20 days before harvest was significantly higher under the CS treatment than under the PS and NS treatments (p.value: 0.01), while no significant difference was observed for spike biomass (p.value: 0.19).

In 2014-15, straw and spike biomass was affected by the shading treatments at the same sampling date but the pattern of biomass reduction with light availability did not follow a clear trend (Fig. 53). In fact, the CS straw and spike biomass were significantly reduced at flowering ( $-37 \%$, p.value: 0.004$)$ as compared to the PS2 treatment. The PS1, PS3 and NS treatment led to an intermediate biomass reduction. At harvest, no significant difference between the treatments was observed for straw biomass (p.value: 0.19 ). Nevertheless, the CS spike biomass was significantly reduced (p.value: 0.004) as compared to the NS and PS2 treatment, while the PS1 and PS3 treatment led to an intermediate biomass reduction (Fig. 53-4). At harvest, there is no significant differences between the PS (1246.88 g/ $\mathrm{m}^{2}$ ) and the NS treatment (p.value: 0.001 ) when looking at the PS treatment as a whole.

Finally, the shade treatment influenced the relative contribution of the different parts of the plant (grain, straw, and glume) to the final aboveground DM. In 2015, the grain biomass accounted for $52 \%$ of total aboveground DM under NS and 38\% under CS at harvest time (Fig. 6). The large differences in biomass components observed 

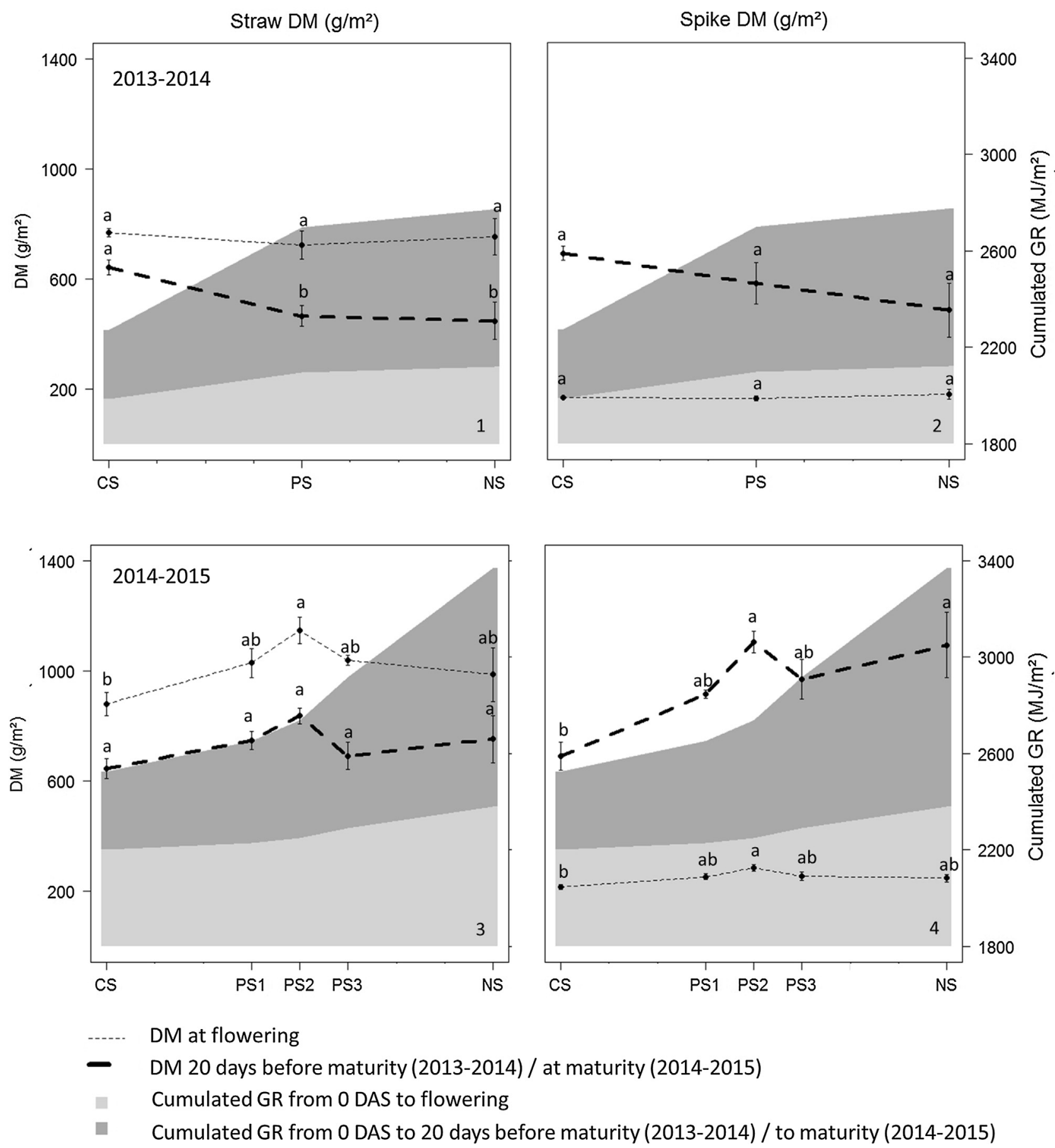

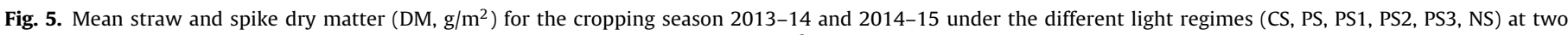

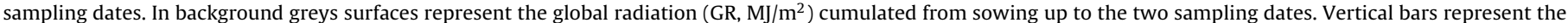
standard error of the means.

between the 2 years can be explained by the occurrence of take-all disease in 2014 and particularly favorable weather conditions for winter wheat in 2015.

\subsection{Shading effect on wheat production and yield components}

In both years, final grain yield was highest under NS conditions and declined with increased shade. The CS treatment induced the maximum yield reduction ( $-29 \%$ in 2014 and $-45 \%$ in 2015) while the PS treatment led to intermediate productivity as presented in Table 2 . The correlation between final grain yield and shade inten- sity was not linear. Using the three sensors in the PS treatment, we can study this relationship in more detail. In 2015, grain yield was higher under PS2 $\left(10.27 \mathrm{tha}^{-1}\right)$ than under PS1 $\left(8.37 \mathrm{tha}^{-1}\right)$ and PS3 (9.12 tha $\mathrm{th}^{-1}$ ) although it received an intermediate global radiation reduction (45\%) compared to the PS1 (52\%) and PS3 (33\%) treatments (Tables 1 and 2). Shade treatments not only influenced the total yield, but also the yield components (i.e. number of grain per $\mathrm{m} 2$, number of grains per spike, grain dry weight and grain size). In both experimental years, the CS reduced the number of grains per spike (by 30\% in 2014 and 20\% in 2015) as well as the thousand grain weight (by $10 \%$ in 2014 and 32\% in 2015) (Table 2). 
Table 1

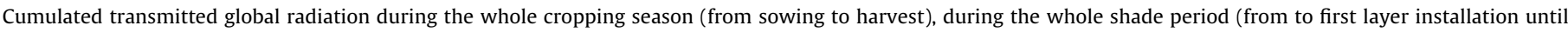
layers remove) and during the 3 phenological period for the artificial shades treatments (PS, PS1, PS2, PS3, CS) and the control plot (NS).

\begin{tabular}{|c|c|c|c|c|c|c|}
\hline \multirow[b]{3}{*}{ 2013-2014 } & \multirow[b]{3}{*}{ Days after sowing } & \multicolumn{5}{|c|}{ Cumulated transmitted global radiation $\left(\mathrm{MJ} / \mathrm{m}^{2}\right)$ - Percentage of transmitted global radiation (\%) } \\
\hline & & Cropping season & Whole shades period & Sowing to $\mathrm{LAI}_{\max }$ & $\mathrm{LAI}_{\max }$ to flowering & Flowering to harvest \\
\hline & & $0-285$ & $213-274$ & $0-200$ & $201-229$ & $230-285$ \\
\hline \multirow{11}{*}{ 2014-2015 } & NS & $3174-100$ & $1177-100$ & \multirow[t]{4}{*}{$1511-100$} & $612-100$ & $1051-100$ \\
\hline & PS & $2986-94$ & $988-84$ & & $566-82$ & $909-86$ \\
\hline & PS1 & 3084-97 & 1084-92 & & 589-96 & $983-94$ \\
\hline & CS & $2565-81$ & $567-48$ & & $479-78$ & $574-55$ \\
\hline & Days after sowing & $0-292$ & $226-292$ & $0-211$ & $212-235$ & $236-292$ \\
\hline & NS & $3398-100$ & $1414-100$ & \multirow[t]{6}{*}{$1698-100$} & $565-100$ & $1135-100$ \\
\hline & PS & $2788-82$ & $804-57$ & & $477-84$ & $613-54$ \\
\hline & PS1 & $2664-78$ & $680-48$ & & $458-81$ & $508-45$ \\
\hline & PS2 & $2755-81$ & $771-55$ & & $474-84$ & $583-51$ \\
\hline & PS3 & $2936-86$ & $953-67$ & & $501-89$ & $737-65$ \\
\hline & CS & $2535-75$ & $551-39$ & & $438-78$ & 399-35 \\
\hline
\end{tabular}

Table 2

Mean value of yield, yield components and protein content of winter-wheat for each treatment.

\begin{tabular}{|c|c|c|c|c|c|c|c|}
\hline & $\mathrm{Nb}$ grain/spikes & $\mathrm{Nb}$ grain $/ \mathrm{m}^{2}$ & Thousand grain weight $(\mathrm{g})$ & Yield (t/ha) & Harvest Index & Protein (\%) & Protein yield (t/ha) \\
\hline \multicolumn{8}{|l|}{ 2013-2014 } \\
\hline NS & $41 \pm 3.46^{a}$ & $13997 \pm 1171^{\mathrm{a}}$ & $46.50 \pm 0.67^{a}$ & $6.52 \pm 1.24^{\mathrm{a}}$ & & $12.25 \pm 0.39^{a}$ & $0.80 \pm 0.12^{\mathrm{a}}$ \\
\hline PS & & $13581 \pm 767^{a}$ & $46.37 \pm 1.03^{a}$ & $6.31 \pm 0.91^{a}$ & & $12.65 \pm 0.33^{a}$ & $0.80 \pm 0.17^{a}$ \\
\hline CS & $29 \pm 4.12^{b}$ & $11120 \pm 609^{a}$ & $42 \pm 0.23^{b}$ & $4.67 \pm 0.55^{\mathrm{a}}$ & & $13.52 \pm 0.34^{a}$ & $0.63 \pm 0.06^{a}$ \\
\hline ANOVA-p.value & 0.001 & 0.09 & 0.003 & 0.042 & & 0.002 & 0.16 \\
\hline \multicolumn{8}{|l|}{ 2014-2015 } \\
\hline NS & $59 \pm 2.5^{\mathrm{a}}$ & $26375 \pm 1106^{a}$ & $49.19 \pm 0.95^{\mathrm{a}}$ & $12.96 \pm 0.14^{\mathrm{a}}$ & $0.52 \pm 0.045^{\mathrm{a}}$ & $10.97 \pm 0.17^{\mathrm{a}}$ & $1.42 \pm 0.01^{\mathrm{a}}$ \\
\hline PS & & $22762 \pm 1182^{b}$ & $42.95 \pm 1.87^{b}$ & $9.76 \pm 0.2^{b}$ & $0.47 \pm 0.027$ & $13.30 \pm 0.31^{b}$ & $1.30 \pm 0.01^{b}$ \\
\hline $\mathrm{PS}_{1}$ & $41 \pm 5.31^{b}$ & $20574 \pm 2643$ & $40.71 \pm 4.06$ & $8.37 \pm 0.21$ & $0.43 \pm 0.018$ & & \\
\hline $\mathrm{PS}_{2}$ & $45 \pm 3.86^{b}$ & $23633 \pm 2032$ & $43.51 \pm 1.35$ & $10.27 \pm 0.77$ & $0.46 \pm 0.009$ & & \\
\hline $\mathrm{PS}_{3}$ & $41 \pm 6.29^{b}$ & $19385 \pm 2979$ & $47.08 \pm 1.72$ & $9.12 \pm 1.38$ & $0.47 \pm 0.006$ & & \\
\hline $\mathrm{CS}$ & $47 \pm 0.96^{b}$ & $21519 \pm 452^{b}$ & $33.20 \pm 0.99^{c}$ & $7.14 \pm 0.14^{c}$ & $0.38 \pm 0.022^{b}$ & $15.92 \pm 0.47^{c}$ & $1.14 \pm 0.02^{c}$ \\
\hline ANOVA-p.value & 0.00013 & 0.00015 & 1.46. $10^{-7}$ & 1.37. $10^{-10}$ & 0.01 & 3.09. $10^{-8}$ & $1.42 .10^{-6}$ \\
\hline
\end{tabular}

The intervals are \pm the standard errors. Parameters with the same letter are not significantly different from each other at the chosen level (Tukey's HSD, P $<0.05$ ).

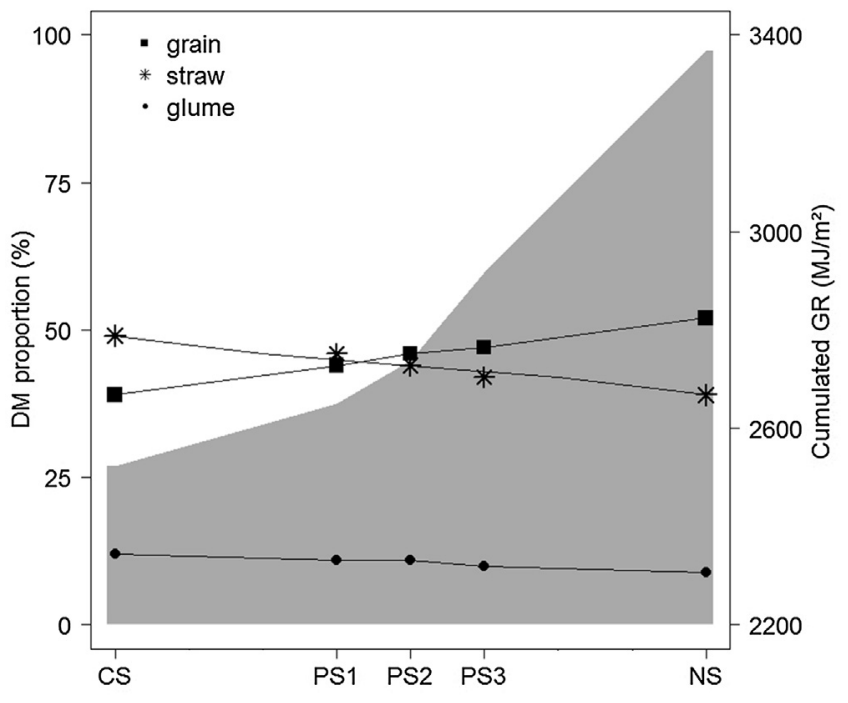

Fig. 6. Proportion of grain, straw and glume DM (\%) to the total aboveground biomass under the different shade treatment at harvest for the season 2014-2015. In background dark grey plot represent the global radiation (GR, $\mathrm{MJ} / \mathrm{m}^{2}$ ) cumulated from sowing to harvest.

Moreover, it led to a reduced proportion of large grain sizes (sieve $2.8 \mathrm{~mm}$ ), a large proportion of medium (sieve $2.5 \mathrm{~mm}$ ) and small (sieve $2.2 \mathrm{~mm}$ ) grain sizes 286 as compared to NS and PS (Fig. 7). Within the PS treatment, the different shade intensities (PS1, PS2, and PS3) of both years were not significantly different in terms of the number of grains per spike, but in 2015 the thousand grain weight and the number of grain per $\mathrm{m} 2$ decreased with increasing shade. Overall, shade application had a negative impact on the proportion of large and medium grain sizes, favoring smaller ones (see Fig. 7). Finally, there was a positive influence of shade on the quality of the winter wheat grains. In both years, the protein concentration in the grain increased with increasing shade (Table 2), but the trend was only significant in 2015 (p.value: $3.09 .10^{-6}$ ). Nevertheless, at the plot scale, this protein content gain did not compensate the decrease in final grain yield. In 2015, winter-wheat under CS and PS treatment achieved significantly lower total protein yield than the NS treatment $\left(-20 \%\right.$ and $-8 \%$ respectively, pvalue: $1.42 .10^{-6}$ ).

\subsection{Long term radiation availability under agroforestry system: modelling approach}

Fig. 8. tracks the distribution, in terms of proportion of cropped area, of the predicted relative global radiation available for the understory crop over 50 years under east-west and north-south tree orientation. During the first decade the cropped area as a whole receives between 100 and $80 \%$ of light. After that, the proportion of area affected by a reduced light availability increases with tree growth whatever the orientation of the tree lines. Nevertheless, under the E-W orientation a more heterogeneous distribution of light availability is to be expected with a strong gradient ranging from $20 \%$ to $100 \%$ in the fortieth year. The, crops growing under the $\mathrm{N}-\mathrm{S}$ tree lines never experience a reduction of light availability lower than $40 \%$. In fact, the area of strong shade is mainly located under uncultivated zone under the tree lines. Comparing this simulation to our field data, we can state that the conditions recorded 

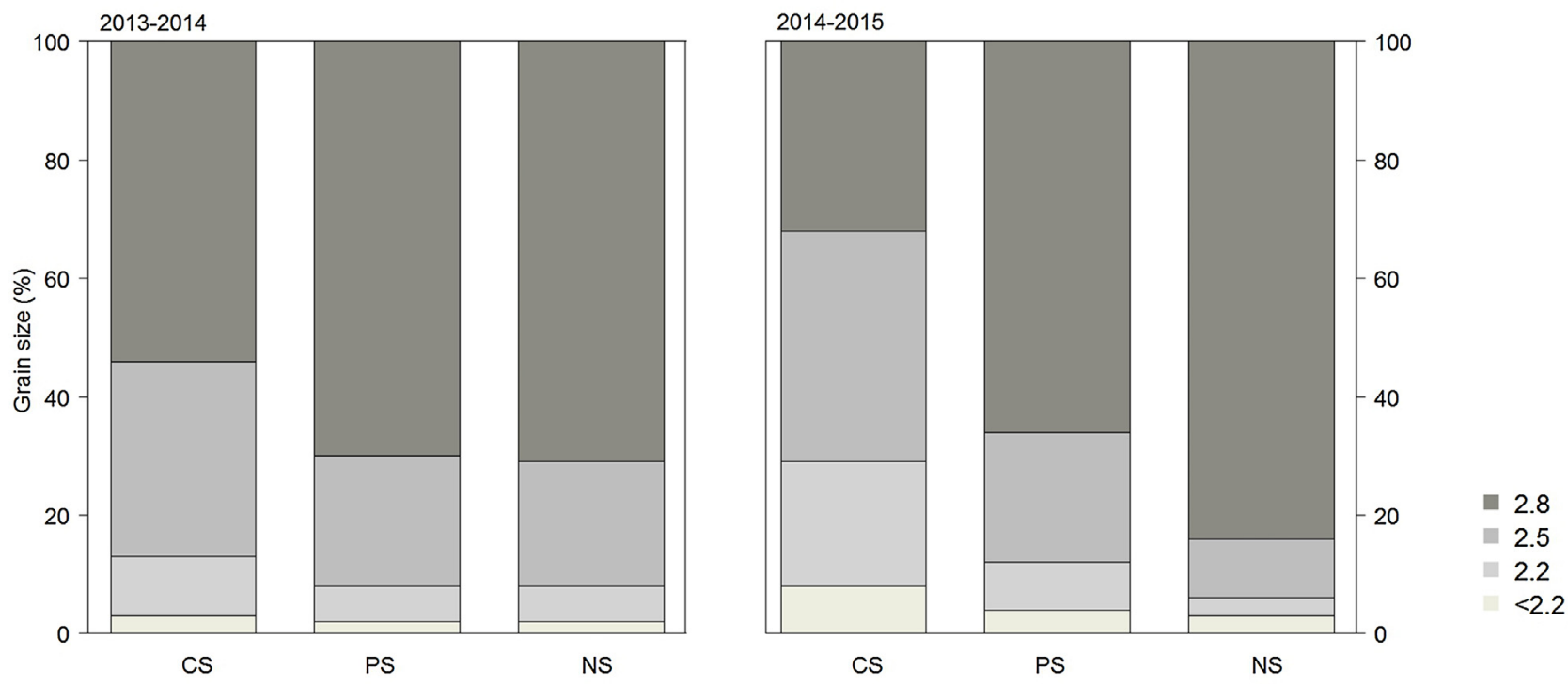

Fig. 7. Proportion of grain size ( $2.8 \mathrm{~mm} ; 2.5 \mathrm{~mm}, 2.2 \mathrm{~mm}$ and less than $2.2 \mathrm{~mm})$ under the different shade treatment for the two cropping season $2013-14$ and $2014-15$.
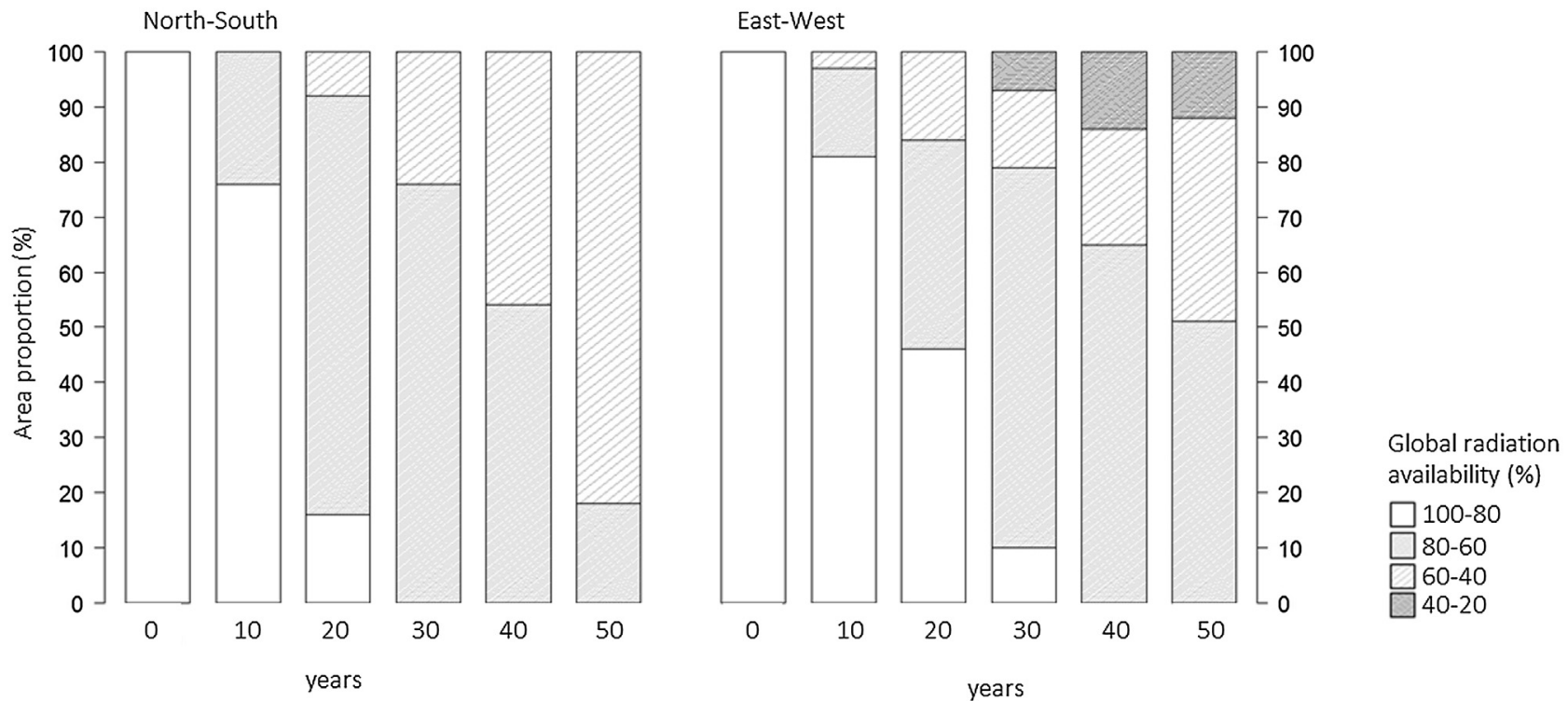

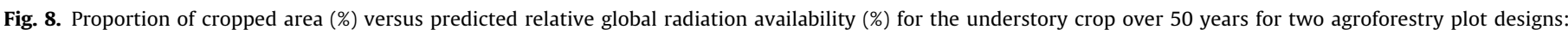
east-west and north-south tree line orientation.

under the PS treatment during the whole shade period (57\% of light availability) would only be reached on a small proportion of the cropped area (less than 10\%) in a real agroforestry system and this from the second and third years onward for the N-S and E-W tree line orientation respectively. For 50 years old trees, the proportion of area receiving this light condition is larger under the N-S orientation ( $80 \%$ of the cropped area) than under the E-W one $(40 \%$ of the cropped area). The values recorded under the CS shade treatment (39\% of light availability) would be achieved only under the E-W orientation from the fortieth years onward and on $10 \%$ of the cropped area.

\section{Discussion}

Several authors have shown that reducing incident light on a wheat crop leads to growth and yield repercussions and our study is no exception (Chirko et al., 1996; Dufour et al., 2013; Li et al., 2010; Mu et al., 2010). According to these studies, the magnitude of wheat response varies with the level and period of shade application. Furthermore, the crop components, such as final grain yield, are related in a non-linear way to the reduction in cumulative global radiation from sowing date to harvest. Dufour et al. (2013) and Li et al. (2008) reported that an average reduction of transmitted cumulated global radiation by $17 \%$ or $34 \%$ led to an average yield depression of $20 \%$ and $51 \%$ respectively. Here, we demonstrated that a reduction of $61 \%$ and $43 \%$ of the global radiation cumulated during the shade period induced a final yield reduction of $45 \%$ and $25 \%$ respectively under CS and PS treatment, in 2015. Under the PS1, PS2 and PS3 treatment the pattern is somewhat more complex since the PS2 treatment remains not significantly different from the NS treatment, although the global radiation available for the winter wheat is reduced by $45 \%$ as compared to the NS treatment. In these studies and in our experiment, the wheat plants grew in a complex light environment, which varies in intensity, frequency and space. Therefore, daily carbon gain and final yield cannot only be estimated from an average value of the global radiation over the whole 
cropping season. In fact, studies have highlighted the non-linear response of photosynthesis to light, particularly for plants growing in fluctuating and heterogeneous environments (Pearcy et al., 1996; Retkute et al., 2015). In fact, a developmental and dynamic acclimation process can takes place (i.e. a change in LAI or leaf shape during the leaf development, relative concentration of proteins, chlorophyll content, ...) to maintain a specific level of photosynthesis which is both related to the instantaneous environmental signal and the information from the past (Li et al., 2010; Murchie and Niyogi, 2011; Retkute et al., 2015). This raises questions about the potential to generalize results from our experimental design in which the shade treatments applied induced a sharp change in global radiation for the crop, whereas shade intensity increases progressively in a real agroforestry system. In their field experiment, Li et al. (2010) found that applying shade between jointing and maturity leads to an increase in area of the upper leaves, in length of the internode and in pigment content. Under the low intensity shading treatments (i.e. reduction of 8 and $15 \%$ of full radiation) the responses of these traits led to an increased final yield for the shade tolerant wheat cultivar. These physiological and morphological compensations allow yield to be maintained even under heavy shade and therefore relative yield loss (5.9\%) was significantly lower than the relative global radiation reduction (27\%). In our experiment, no morphological adaptation was observed on wheat as the shade treatment was applied after the LAImax phenological stage. Photoacclimation could have occurred under our shade treatment, but to assess that correctly we would have needed complementary measurements such as photosynthetic rates. Furthermore, Murchie and Niyogi (2011) emphasizes that the photosynthetic adaptation (photoacclimation) of a plant to a new light environment takes place on a timescale of days, but uncertainty remains in fluctuating light environments (Retkute et al., 2015). In addition, several authors have shown that dynamic photoacclimation is highly dependent on species (Athanasiou et al., 2010; Murchie and Niyogi, 2011; Retkute et al., 2015). Retkute et al. (2015) argues that crop breeding programs should take acclimation traits into consideration in order to select shade tolerant cultivars. This suggestion is highly relevant in the context of agroforestry as most of the crop species currently used were selected in full light conditions, and have potentially inefficient photoacclimation traits. Several authors concluded that the success of agroforestry systems depends on the selection of shade-tolerant species (Barro et al., 2012; Ehret et al., 2015). This last point highlights that crop cultivar is an important factor which may explain the differences found in the literature considering crop response to light environment. Furthermore, the effect of global radiation reduction on final yield depends on the phenological stage during which shade is applied, as well as the duration of the period in which the incident light is reduced. In wheat, several authors have demonstrated that imposing a shade treatment during the pre-flowering period (i.e. around 30 days before-to flowering) mainly affected final yield through the number of grain per $\mathrm{m} 2$ component because of a change of numbers of grains per spike (Abbate et al., 1997; Demotes-Mainard and Jeuffroy, 2004; Fischer and Stockman, 1980). However, shade from flowering to maturity reduced both number of grain per $\mathrm{m} 2$ and grain weight (Estrada-Campuzano et al., 2008). Our results support these observations. In fact, both yield components were affected in 2015 as shade was applied 10 to 16 days before flowering until maturity. Additionally, several authors show that post-flowering shade may impact on grain weight through alteration of the current photosynthetic activity as well as the redistribution of the vegetative reserve to the grains (Herzog, 1986; Plaut et al., 2004; Schnyder, 1993). In this study, the amount of vegetative reserve mobilized to the grain as well as the relative contribution of this pool to final grain yield were the same even with post-flowering shade. Thus, the reduction of grain weight under shade treatment can most probably be explained by a decrease of the pool of assimilates produced by photosynthesis during grain filling. Finally, grain yield, as well as grain protein concentration, has to be taken into consideration when evaluating the wheat production: quantity and quality (protein content). Just like Dufour et al. (2013), we measured an increase of protein grain content with increasing shade intensity, but the increase did not compensate the final yield decrease. The protein content of the grain resulted from the remobilization of $\mathrm{N}$ accumulated by the plant and is negatively related to final grain yield due to a dilution effect. Our results from the disease-free year clearly illustrates this process, as under the shade treatment, higher grain protein content is associated with a higher proportion of small grain sizes and with a lower final yield. The first year did not show this pattern since the take-all disease caused an overall yield reduction. In 2013-14, there were no significant differences in final yield, nor in protein content between treatments. Take-all disease is known to negatively affect wheat grain filling by disrupting water and nutrient uptake and flows through the plant (Kwak and Weller, 2013). Even though the 2013-2014 results are not representative for a healthy wheat field, they do show the resilience of silvoarable agroforestry systems to disease occurrence. Our data reveal that the shade treatments were less affected by the disease. This can be explained by the fact that under the CS treatment the green leaf area of winter wheat was maintained during a longer period than under NS and PS. This persistence of green leaves can enhance the final yield by extending the period of carbon assimilation.

The artificial shade implemented in the experiment represented an extreme level of shade. The CS treatment created a strong shade environment corresponding to old trees and dense plantation densities or east-west tree orientation, whereas the PS treatments represented lower shade environments corresponding to younger trees, and/or open plantation density. However, in agroforestry, specific pruning practices and other management decisions can greatly influence on the light environment of the crop. In view of the great diversity of agroforestry systems, it remains difficult to associate the current experiment to a specific agroforestry system light environment.

Keeping this in mind, our observed yield decrease of $45 \%$ in 2014-2015 under CS treatment is not very likely to occur under agroforestry and should be seen as a worst-case scenario. In fact, this configuration of high density canopy closure between the tree rows is unrealistic since these are now planted at wide-spacing matching the width of agricultural machinery. According to the Hi-sAFe simulation, the global radiation available for crops should remain above $60 \%$ on at least $50 \%$ of the cropped area during the first 40 years of growth of a simulated real agroforestry plot with north-south tree line orientation, and will never reach the intensity of the CS shade treatment even under 50-year-old trees. Thus, under a tree configuration realistic for the agricultural practices in temperate regions, large shade effects can be expected only after 30 years of the tree rotation with an E-W tree orientation. The data observed under the PS treatment therefore is more realistic of natural sunfleck shade environments in agroforestry.

Finally, the artificial shade structure allowed us to separate the effect of light resources from other potential biotic and abiotic interactions in agroforestry systems. Thus, under the artificial shade treatment we certainly underestimate the effect of a real agroforestry system on crop yield. A number of studies with crops such as soybean (Reynolds et al., 2007; Rivest et al., 2009), corn (Reynolds et al., 2007), winter wheat (Chirko et al., 1996; Dufour et al., 2013; Li et al., 2008), alfalfa (Varella et al., 2010) or forage mixture (Bouttier et al., 2014) displayed similar trend for the relative yield (ratio between intercrops yield and sole crop yield) but the magnitude of the competition often differs and varied from 0.42 to 0.83 . Focusing on wheat, Dufour et al. (2013) provided some insights on yield responses to shade and to the other possi- 
ble interactions by comparing durum wheat growing under a real agroforestry system and artificial shade treatment in the south of France. In this study, the reduction of final yield was higher $(-20 \%)$ under their real agroforestry treatment in Restinclières than under their artificial shade treatment (-16\%), even though the light reduction integrated over the whole growing season was comparable for both scenarios ( $-17 \%$ and $-19 \%$, respectively). Thus, field trials testing the same annual crops intercropped with deciduous trees have established contrasted relative yield results, even in contexts where the competition for light was probably of similar intensity. The behavior of a crop to shade is highly dependent on growth conditions, including climate, the species variety and management practice.

\section{Conclusion}

The experimental setup presented in this research paper reproduced the effect of the heterogeneous spatio-temporal pattern of light observed under trees in an agroforestry system, and isolated it from competition effects for water and nutrients. Winter wheat responded to the late application of shade by a significant decrease of grain yield, which was partly compensated by an increase in the grain protein content. These first results in Belgium provide an understanding of the functioning of wheat under shade in field conditions and may help adapt agroforestry practices to north temperate latitudes. Future research should be conducted to integrate other tree-crop-environment interactions, such as nutrient and water availability, or pest occurrence, in order to have an improved view of the complex interactions in agroforestry systems. Furthermore, it remains necessary to monitor tree productivity and economic value in the research to evaluate in how far the revenue from the trees can compensate for the modest overall decrease in crop yield.

\section{Acknowledgements}

We thank the University of Liège-Gembloux Agro-Bio Tech and more specifically the research platform AgricultureIsLife for the funding of this research project. We also wish to thank the technicians, as well as B. Bodson, director of the experimental farm, for their help with the field and forest experiment. We also wish to thank the two anonymous reviewers for their helpful comments. The data of this paper are available online on zenodo.org with DOI $10.5281 /$ zenodo.158965.

\section{Bibliography}

Abbate, P.E., Andrade, F.H., Culot, J.P., Bindraban, P.S., 1997. Grain yield in wheat: effects of radiation during spike growth period. Field Crops Res. 54, 245-257.

Athanasiou, K., Dyson, B.C., Webster, R.E., Johnson, G.N., 2010. Dynamic acclimation of photosynthesis increases plant fitness in changing environments. Plant Physiol. 152, 366-373, http://dx.doi.org/10.1104/pp.109.149351.

Bah B.B., Engels P., Colinet G., Bock L., Bracke C., Veron P., 2005. Légende de la Carte Numérique des Sols de Wallonie (Belgique). Sur base de la légende originale de la Carte des sols de la Belgique de l'IRSIA à $1 / 20.000$.

Barro, R.S., Varella, A.C., Lemaire, G., Medeiros, R.B., de Saibro, J.C., de Nabinger, C., Bangel, F.V., Carassai, I.J., 2012. Forage yield and nitrogen nutrition dynamics of warm-season native forage genotypes under two shading levels and in full sunlight. Rev. Bras. Zootec. 41, 1589-1597.

Batish, D., 2008. Ecological Basis of Agroforestry. CRC Press, Boca Raton, FL

Bouttier, L., Paquette, A., Messier, C., Rivest, D., Olivier, A., Cogliastro, A., 2014 Vertical root separation and light interception in a temperate tree-based intercropping system of Eastern Canada. Agrofor. Syst., http://dx.doi.org/10. 1007/s10457-014-9721-6.

Cannell, M.G.R., van Noordwijk, M., Ong, C.K., 1996. The central agroforestry hypothesis: the trees must acquire resources that the crop would not otherwise acquire. Agrofor. Syst. 34, 27-31.

Chirko, C.P., Gold, M.A., Nguyen, P.V., Jiang, J.P., 1996. Influence of direction and distance from trees on wheat yield and photosynthetic photon flux density in a Paulownia and wheat intercropping system. For. Ecol. Manag. 83, 171-180.
Demotes-Mainard, S., Jeuffroy, M.-H., 2004. Effects of nitrogen and radiation on dry matter and nitrogen accumulation in the spike of winter wheat. Field Crops Res. 87, 221-233, http://dx.doi.org/10.1016/j.fcr.2003.11.014.

Dufour, L., Metay, A., Talbot, G., Dupraz, C., 2013. Assessing light competition for cereal production in temperate agroforestry systems using experimentation and crop modelling. J. Agron. Crop Sci. 199, 217-227, http://dx.doi.org/10. $1111 /$ jac. 12008 .

Dupraz, C., Burgess, P., Gavaland, A., Graves, A., Herzog, F., Incoll, L.D., Jackson, N., Kessman, K., Lawson, G., Lecomte, I., Liagre, F., Mantzanas, K., Mayus, M., Moreno, G., Palma, J., Papanastasis, V., Paris, P., Pilbeam, D., Reisner, Y., Werf Van der, W., 2005. SAFE Final Report (Technical Report No. Silvoarable Agroforestry for Europe (SAFE) European Research Contract QLK5-CT-2001-00560). INRA-UMR Systems Editions, Montpellier.

Dupraz, C., 2002. Tree-crop Interaction Models: State of the Art Report (Technical Report No. Deliverable D.1.1 of the SAFE European Research Contract QLK5-CT-2001-00560). INRA, Montpellier.

Ehret, M., Graß, R., Wachendorf, M., 2015. The effect of shade and shade material on white clover/perennial ryegrass mixtures for temperate agroforestry systems. Agrofor. Syst. 89, 557-570, http://dx.doi.org/10.1007/s10457-015-9791-0.

Eichhorn, M.P., Paris, P., Herzog, F., Incoll, L.D., Liagre, F., Mantzanas, K., Mayus, M., Moreno, G., Papanastasis, V.P., Pilbeam, D.J., Pisanelli, A., Dupraz, C., 2006. Silvoarable systems in Europe-past, present and future prospects. Agrofor. Syst. 67, 29-50, http://dx.doi.org/10.1007/s10457-005-1111-7.

Estrada-Campuzano, G., Miralles, D.J., Slafer, G.A., 2008. Yield determination in triticale as affected by radiation in different development phases. Eur. J. Agron. 28, 597-605, http://dx.doi.org/10.1016/j.eja.2008.01.003.

FAO, 2014. World Reference Base for Soil Resources 2014 International Soil Classification System for Naming Soils and Creating Legends for Soil Maps. FAO, Rome.

Fischer, R.A., Stockman, Y.M., 1980. Kernel number per spike in wheat (Triticum aestivum L.): responses to preanthesis shading. Funct. Plant Biol. 7, 169-180.

Friday, J.B., Fownes, J.H., 2002. Competition for light between hedgerows and maize in an alley cropping system in Hawaii, USA. Agrofor. Syst. 55, 125-137.

Gillespie, A.R., Jose, S., Mengel, D.B., Hoover, W.L., Pope, P.E., Seifert, J.R., Biehle, D.J., Stall, T., Benjamin, T.J., 2000. Defining competition vectors in a temperate alley cropping system in the midwestern USA: 1. Production Physiology. Agrofor. Syst. 48, 25-40.

Grisso, R.D., Alley, M.M., Holshouser, D.L., Thomason, W.E., 2005. Precision farming tools. Soil Electr. Conduct.

Herzog, H., 1986. Source and sink during the reproductive period of wheat. In: Development and its Regulation with Special Reference to Cytokinins. Paul Parey Scientific Pub.

Jose, S., Gordon, A.M. (Eds.), 2008. Advances in Agroforestry. Springer, Dordrecht.

Kwak, Y.-S., Weller, D.M., 2013. Take-all of wheat and natural disease suppression: a review. Plant Pathol. J. 29, 125-135, http://dx.doi.org/10.5423/PPJ.SI.07.2012. 0112.

Leroy, C., Sabatier, S., Wahyuni, N.S., Barczi, J.-F., Dauzat, J., Laurans, M., Auclair, D., 2009. Virtual trees and light capture: a method for optimizing agroforestry stand design. Agrofor. Syst. 77, 37-47, http://dx.doi.org/10.1007/s10457-0099232-z.

Li, F., Meng, P., Fu, D., Wang, B., 2008. Light distribution, photosynthetic rate and yield in a Paulownia-wheat intercropping system in China. Agrofor. Syst. 74, 163-172, http://dx.doi.org/10.1007/s10457-008-9122-9.

Li, H., Jiang, D., Wollenweber, B., Dai, T., Cao, W., 2010. Effects of shading on morphology, physiology and grain yield of winter wheat. Eur. J. Agron. 33, 267-275, http://dx.doi.org/10.1016/j.eja.2010.07.002.

Liu, N., 1991. Light distribution in tree intercropping area and its agricultural value. Agrofor. Syst. China, 14-21.

Luedeling, E., Smethurst, P.J., Baudron, F., Bayala, J., Huth, N.I., van Noordwijk, M., Ong, C.K., Mulia, R., Lusiana, B., Muthuri, C., Sinclair, F.L., 2016. Field-scale modeling of tree-crop interactions: challenges and development needs. Agric. Syst. 142, 51-69, http://dx.doi.org/10.1016/j.agsy.2015.11.005.

Malézieux, E., Crozat, Y., Dupraz, C., Laurans, M., Makowski, D., Ozier-Lafontaine, H., Rapidel, B., Tourdonnet, S., Valantin-Morison, M., 2009. Mixing plant species in cropping systems: concepts, tools and models. A review. Agron. Sustain. Dev. 29, 43-62, http://dx.doi.org/10.1051/agro:2007057.

Mu, H., Jiang, D., Wollenweber, B., Dai, T., Jing, Q., Cao, W., 2010. Long-term low radiation decreases leaf photosynthesis, photochemical efficiency and grain yield in winter wheat. J. Agron. Crop Sci. 196, 38-47, http://dx.doi.org/10.1111/ j.1439-037X.2009.00394.x.

Murchie, E.H., Niyogi, K.K., 2011. Manipulation of photoprotection to improve plant photosynthesis. Plant Physiol. 155, 86-92, http://dx.doi.org/10.1104/pp. 110.168831.

Ong, C.K., Huxley, P.A., 1996. Tree-Crop Interactions - a Physiological Approach. CAB International, Wallingford (UK)

Pearcy, R.W., Krall, J.P., Sassenrath-Cole, G.F., 1996. Photosynthesis in fluctuating light environments. In: Photosynthesis and the Environment. Springer, pp. 321-346.

Peri, P.L., McNeil, D.L., Moot, D.J., Varella, A.C., Lucas, R.J., 2002. Net photosynthetic rate of cocksfoot leaves under continuous and fluctuating shade conditions in the field. Grass Forage Sci. 57, 157-170.

Plaut, Z., Butow, B., Blumenthal, C., Wrigley, C., 2004. Transport of dry matter into developing wheat kernels and its contribution to grain yield under post-anthesis water deficit and elevated temperature. Field Crops Res. 86, 185-198, http://dx.doi.org/10.1016/j.fcr.2003.08.005. 
Retkute, R., Smith-Unna, S.E., Smith, R.W., Burgess, A.J., Jensen, O.E., Johnson, G.N., Preston, S.P., Murchie, E.H., 2015. Exploiting heterogeneous environments: does photosynthetic acclimation optimize carbon gain in fluctuating light? J. Exp Bot. 66, 2437-2447, http://dx.doi.org/10.1093/jxb/erv055.

Reynolds, P.E., Simpson, J.A., Thevathasan, N.V., Gordon, A.M., 2007. Effects of tree competition on corn and soybean photosynthesis, growth, and yield in a temperate tree-based agroforestry intercropping system in southern Ontario, Canada. Ecol. Eng. 29, 362-371, http://dx.doi.org/10.1016/j.ecoleng.2006.09. 024.

Rivest, D., Cogliastro, A., Vanasse, A., Olivier, A., 2009. Production of soybean associated with different hybrid poplar clones in a tree-based intercropping system in southwestern Québec, Canada. Agric. Ecosyst. Environ. 131, 51-60, http://dx.doi.org/10.1016/j.agee.2008.08.011.

Schnyder, H., 1993. The role of carbohydrate storage and redistribution in the source-sink relations of wheat and barley during grain filling - a review. New Physiol. 123, 1469-8137

Smith, J., Pearce, B.D., Wolfe, M.S., 2013. Reconciling productivity with protection of the environment: is temperate agroforestry the answer? Renew. Agric. Food Syst. 28, 80-92, http://dx.doi.org/10.1017/S1742170511000585.

Talbot, G., Dupraz, C., 2012. Simple models for light competition within agroforestry discontinuous tree stands: are leaf clumpiness and light interception by woody parts relevant factors? Agrofor. Syst. 84, 101-116, http://dx.doi.org/10.1007/s10457-011-9418-z.

Tilman, D., Snell-Rood, E.C., 2014. Diversity breeds complementarity. Nature 515, 44.

Tsonkova, P., Böhm, C., Quinkenstein, A., Freese, D., 2012. Ecological benefits provided by alley cropping systems for production of woody biomass in the temperate region: a review. Agrofor. Syst. 85, 133-152, http://dx.doi.org/10. 1007/s10457-012-9494-8.

Varella, A.C., Moot, D.J., Pollock, K.M., Peri, P.L., Lucas, R.J., 2010. Do light and alfalfa responses to cloth and slatted shade represent those measured under an agroforestry system? Agrofor. Syst. 81, 157-173, http://dx.doi.org/10.1007/ s10457-010-9319-6.

Waeyaert, N., 2014. Chiffres clés de l'agriculture. L'agriculture en Belgique en chiffres. (Service Public Fédéral Economie). Direction générale Statistiques Statistics Belgium.

Zhang, L., van der Werf, W., Bastiaans, L., Zhang, S., Li, B., Spiertz, J.H., 2008. Light interception and utilization in relay intercrops of wheat and cotton. Field Crops Res. 107, 29-42.

Zhu, Z., Cai, M., Wang, S., Jiang, Y. (Eds.), 1991. Chinese Academy of Forestry and Intern. Canada Development Research Center. 